\title{
Influences of different organic fertilizers on nutrients of humic sandy soil and on the growth of Spinach (Spinacia oleracea L.)
}

\author{
Andrea Balláné Kovács - Rita Kremper - Ida Kincses - Ágnes Leviczky \\ University of Debrecen Faculty of the Agricultural and Food Sciences and Environmental Management, \\ Institute of Agricultural Chemistry and Soil Science, Debrecen, Hungary \\ kovacsa@agr.unideb.hu
}

\section{SUMMARY}

A greenhouse pot experiment was conducted to compare the effects of manure with different origin (horse, cattle), various bedding

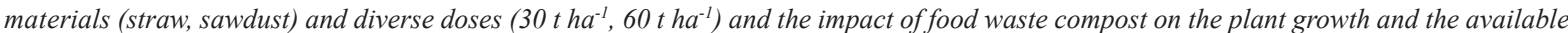
plant nutrient content of soil. The study was conducted on humic sandy soil and consisted of 9 treatments in a randomized complete block design with four replications. Spinach (Spinacia oleracea L.) was grown as the test crop. The treatments were: 1. unfertilized control; 2. horse

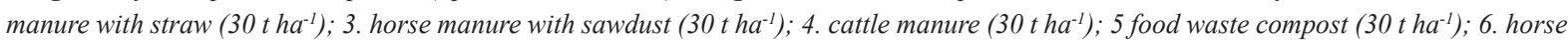

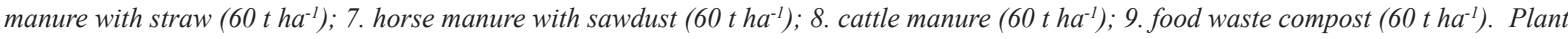
growth was monitored for 4 weeks. Shoot and root weights per pot were measured, total biomass weight per pot were counted.

On the basis of the results it can be concluded, that among treatments the application of horse manure with straw enhanced spinach growth most significantly compared to other treatments and to the non-treated control, resulted the highest weights of leaves and roots of spinach. At the same time even small dose $\left(30 \mathrm{t} \mathrm{ha}^{-1}\right)$ of this fertilizer caused increased plant available nitrogen and phosphorus of soil and the higher dosage further increased these values. The horse manure with sawdust applied in lower dose did not alter the leaves and roots weights,

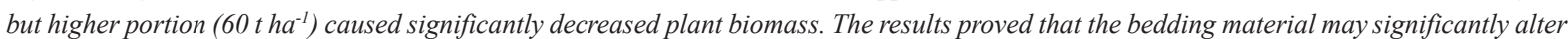
the composition of manure and may change the plant nutrition effect of organic fertilizer. Cattle manure and food waste compost in both applied doses enhanced plant growth. Both fertilizers increased the plant available nitrogen forms and phosphorus content of soil, but cattle manure caused higher increase.

Keywords: manure, food waste compost, spinach, soil, plant nutrients

\section{ÖSSZEFOGLALASS}

Tenyészedényes kísérletben vizsgáltuk a különbözö alomanyaggal (fürészpor, búzaszalma) készült lótrágya, a szarvasmarhatrágya és az ételhulladék komposzt különbözö adagjainak (30 t/ha, 60 t/ha) hatásait a spenót növekedésére és a talaj növény által felvehetö tápanyag-tartalmának változására. A kisérletet humuszos homoktalajon, randomizált blokkelrendezésben állitottuk be kilenc kezeléssel, kezelésenként négy ismétlésben. Tesztnövényként spenótot (Spinacia oleracea L.) alkalmaztunk. A kezelések a következök voltak: 1: kontroll, 2: szalmás lótrágya (30 t/ha), 3: fürészporos lótrágya (30 t/ha), 4: szarvasmarhatrágya (30 t/ha), 5: ételhulladék komposzt (30 t/ha), 6: szalmás lótrágya (60 t/ha), 7: fürészporos lótrágya (60 t/ha), 8: szarvasmarhatrágya (60 t/ha), 9: ételhulladék komposzt (60 t/ha). A spenót növekedését 4 hétig követtük nyomon. Mértük az edényenkénti levél és gyökértömeget, meghatároztuk az edényenként termett összes biomassza tömeget.

Eredményeink alapján elmondható, hogy a kezelések közül a szalmás lótrágya növelte legnagyobb mértékben, statisztikailag is igazolhatóan a spenót tömegét, ebben a kezelésben mértük a legnagyobb levél és gyökértömeget. Ugyanakkor már a kisebb szalmás lótrágyaadag (30 t/ha) hatására is megnövekedett a talajban a növény által felvehetö nitrogén és foszfor mennyisége, a nagyobb adag (60 t/ha) pedig tovább növelte az értékeket. A fürészporos lótrágya kisebb adagja $(30 \mathrm{t} / \mathrm{ha}$ ) nem befolyásolta a spenót növekedését a kontrollhoz viszonyitva, ugyanakkor a nagyobb adagnak (60 t/ha) már kedvezötlen hatását igazoltuk. Eredményeink rámutattak, hogy az alomanyag minösége, a trágya alomanyag eltérö aránya jelentősen befolyásolja a szerves trágya minőségét, növénytápláló hatását. A szarvasmarhatrágya és az ételhulladék komposzt mindkét alkalmazott dózisban növelte a növény biomasszatömegét, fokozta a talajban a növény által felvehetö nitrogén és foszforformák mennyiségét, de a szarvasmarhatrágya hatása nagyobb mértékü volt.

Kulcsszavak: szerves trágya, ételhulladék komposzt, spenót, talaj, tápelemek

\section{INTRODUCTION}

Use of organic fertilizers, which mainly come from crop residues, animal by-products, or might be composts, is one of the oldest methods of soil cultivation (Jongtae, 2010). Organic fertilizers contain specifically high level of organic matter, macronutrients and a variety of micronutrients (Cayuela et al., 2008). Organic materials play key roles of maintaining soil fertility, through increasing microbial activity and plant nutrients of soils (Clark et al., 1998; Liebig and Doran, 1999). Mineral fertilization without organic ones can cause some negative side-effects on the soil properties (Vágó et al., 2015). In recent years the application of organic fertilizers has received great attention in sustainable agriculture (Irshad et al., 2002). They might have been major components of organic farming, which offer an economically and ecologically attractive means of reducing external inputs and improving internal resources (Saxena and Tilak, 1994; Pathak et al., 1997).

Different kinds of organic amendments including farmyard manure (Hati et al., 2008), composts (Sharpley and Moyer, 2000) have been applied to enhance both crop yield and soil quality all over the word. Farmed animals might be a variety of animals like pigs, horses, cattles etc. The expression of "solid manure" means when farmed animals are kept on bedding material which is collected together with all excreta. Quality 
and composition of manures from various domestic animals are mostly significantly different.

The domestication of horses and their use in sport and leisure activities are closely linked with housing. The management and composting of horse manure can be improved by choosing bedding material. Bedding materials may be recycled book paper, sawdust, and straw. Bedding has effects on air, the volume and quality of manure as well. Differences have been found in the process of composting horse manure bedding with sawdust or straw, which may affect the hygiene of the compost product (Fleming et al., 2008).

The European Union Landfill Directive (Council of Europian Union, 1999) required the Member States to reduce the amount of biodegradable waste being dumped and improve activities, such as recovery and recycling. Food waste is large component of the waste stream by weight and constitutes in Hungary. Hotels, restaurants, food chains, food factories and canteens of schools produce million tons of commercial organic waste that may be composted. If these wastes can be composted, this may represent one of the alternatives for achieving the goal of ensuring integrated and sustainable waste management (Elherradi et al., 2005, Cegarra et al., 2006). Food waste compost is generally higher in nutrient values and lower in other contamination than most types of composts, thus making it more valuable in the market (Roberts et al., 2007; Chang and Hsu, 2008). While programs and facilities to manage any waste are well established, the management of food waste in collecting for treatment in central composting facilities is perhaps only in its infancy (Levis et al., 2010).

The aim of the experiment was to compare the effects of manure of various farmed animals (horse, cattle), the effects of horse manure with diverse bedding materials (straw, sawdust), the effect of food waste compost and the impacts of their different doses $\left(30 \mathrm{tha}^{-1}\right.$ and $60 \mathrm{tha}^{-1}$ ) on biomass production of spinach and on plant available nutrients of sandy soil.

\section{MATERIAL AND METHODS}

The greenhouse pot experiment was performed on spinach (Spinacia oleracea L.) in a humic sandy soil. Some properties of soil used in trial are included in Table 1.

The soil was characterized by low organic matter, good phosphorus and good potassium availability. $3 \mathrm{~kg}$ air-dried soil was weighed into Mitscherlich type pots. The aim of conducted greenhouse pot experiment was to compare the effects of different organic fertilizers, like manure with different origin (horse, cattle) and with different bedding materials (straw, sawdust) and the effect of food waste compost on the yield of spinach (Spinacia oleracea L.) and the plant available nutrient content of soil. The organic fertilizers were applied in $30 \mathrm{tha}^{-1}$ and $60 \mathrm{t} \mathrm{ha}^{-1}$ amount. The experiment was set up in a complete randomized design with four replicates and nine treatments. The horse manure was made from two different bedding materials such straw and sawdust, which resulted in mainly different composition of the two types of them. For the treatment applied and the doses of fertilizers see Table 2.

Table 1.

Characteristics of the experimental soil

\begin{tabular}{lc}
\hline $\mathrm{pH}_{\mathrm{CaCl}_{2}}$ & 6.01 \\
$\mathrm{~K}_{\mathrm{A}}$ & 26 \\
$\mathrm{Hu} \%$ & 1.3 \\
$\mathrm{AL}-\mathrm{P}_{2} \mathrm{O}_{5}$ (mg kg-1) & 274 \\
$\mathrm{AL}-\mathrm{K}_{2} \mathrm{O}$ (mg kg-1) & 286 \\
\hline
\end{tabular}

Note: KA - soil plasticity index according to Arany, described by Buzás (1993)

Table 2.

Scheme of treatments applied

\begin{tabular}{lc}
\hline \multicolumn{1}{c}{ Treatments } & $\begin{array}{c}\text { Dose of organic fertilizer } \\
\left(\mathrm{t} \mathrm{ha}^{-1}\right)\end{array}$ \\
\hline 1. unfertilized control & 0 \\
2. horse manure with straw & 30 \\
3. horse manure with sawdust & 30 \\
4. cattle manure & 30 \\
5. food waste compost & 30 \\
6. horse manure with straw & 60 \\
7. horse manure with sawdust & 60 \\
8. cattle manure & 60 \\
9. food waste compost & 60 \\
\hline
\end{tabular}

Compost was obtained from restaurant food residuals. Food residuals were mixed with wood waste and were composted for a total of 90 days. The main characteristics of different organic fertilizers are described in Table 3.

All manures and compost were thoroughly mixed with the soil four weeks before the start of the experiment in order to organic matter could be able to mineralise. Ion exchanged water was added to all pots to keep the soil at constant moisture $(60 \%$ of the water-holding capacity) using daily weighing.

The indicator plant was spinach of variety of "Standard Matador". After germination plants had been grown for four weeks. At the end of the vegetation period leaves and roots were collected from all pots. Fresh weights of leaves and after drying at $60{ }^{\circ} \mathrm{C}$, dry matter accumulation of leaves and roots were determined. The total biomass of spinach per pot was counted by the sum of leaves weight and root weight of pot.

Characteristics of organic fertilizers applied

\begin{tabular}{|c|c|c|c|c|c|c|c|c|}
\hline & $\begin{array}{c}\mathrm{N} \\
(\%)\end{array}$ & $\begin{array}{c}\mathrm{C} \\
(\%) \\
\end{array}$ & $\mathrm{C} / \mathrm{N}$ & $\begin{array}{c}\mathrm{S} \\
(\%)\end{array}$ & $\begin{array}{c}\mathrm{P} \\
(\%) \\
\end{array}$ & $\begin{array}{c}\mathrm{K} \\
(\%) \\
\end{array}$ & $\begin{array}{r}\mathrm{AL}-\mathrm{P}_{2} \mathrm{O}_{5} \\
\left(\mathrm{mg} \mathrm{kg}^{-1}\right) \\
\end{array}$ & $\begin{array}{c}\mathrm{AL}-\mathrm{K}_{2} \mathrm{O} \\
\left(\mathrm{g} 100 \mathrm{~g}^{-1}\right)\end{array}$ \\
\hline Horse manure with straw & 3.870 & 31.90 & 8.24 & 0.595 & 0.625 & 4.85 & 820 & 4.030 \\
\hline Horse manure with sawdust & 0.980 & 11.64 & 11.88 & 0.657 & 0.425 & 2.40 & 730 & 0.939 \\
\hline Cattle manure & 2.310 & 27.22 & 11.79 & 1.059 & 0.400 & 2.65 & 670 & 1.359 \\
\hline Food waste compost & 0.841 & 13.65 & 16.22 & 0.211 & 0.415 & 2.31 & 714 & 0.673 \\
\hline
\end{tabular}


Soil samples were collected from all pots and were air dried and sieved $(<2 \mathrm{~mm})$ for further analysis. Concentration of water soluble nitrogen forms $\left(\mathrm{NO}_{3}-\mathrm{N}\right.$, $\mathrm{NH}_{4}{ }^{+}-\mathrm{N}$, organic- $\mathrm{N}$ and total-N) were measured in $0.01 \mathrm{M} \mathrm{CaCl}_{2}$ extracts with 1:10 soil:solution ratio (Houba et al., 1991; Jászberényi et al., 1994) by an auto-analyser (SKALAR Segment Flow Analyser). The soluble organic-N was calculated by the difference of soluble total-N and the sum of $\mathrm{NO}_{3}-\mathrm{N}$ and $\mathrm{NH}_{4}{ }^{+}-\mathrm{N}$. Concentration of phosphorus and potassium in the soil taken up easily by plant were determined in ammonium lactate-acetic acid (AL) extract. Phosphorus was measured spectrophotometrically, while potassium was quantified by flame emission spectrophotometry.
Analysis of variance (two-way ANOVA) was carried out on the data in order to provide a statistical comparison between the treatment means. The least significant difference (LSD) test $(\mathrm{P}=0.05)$ was used to detect differences between means.

\section{RESULTS AND DISCUSSION}

Growth response of spinach to soil-fertility treatments

The changes of weights of leaves, roots and total biomass of spinach as a function of the treatments are presented in Figures 1-3.

Figure 1: Means of weights of leaves of spinach

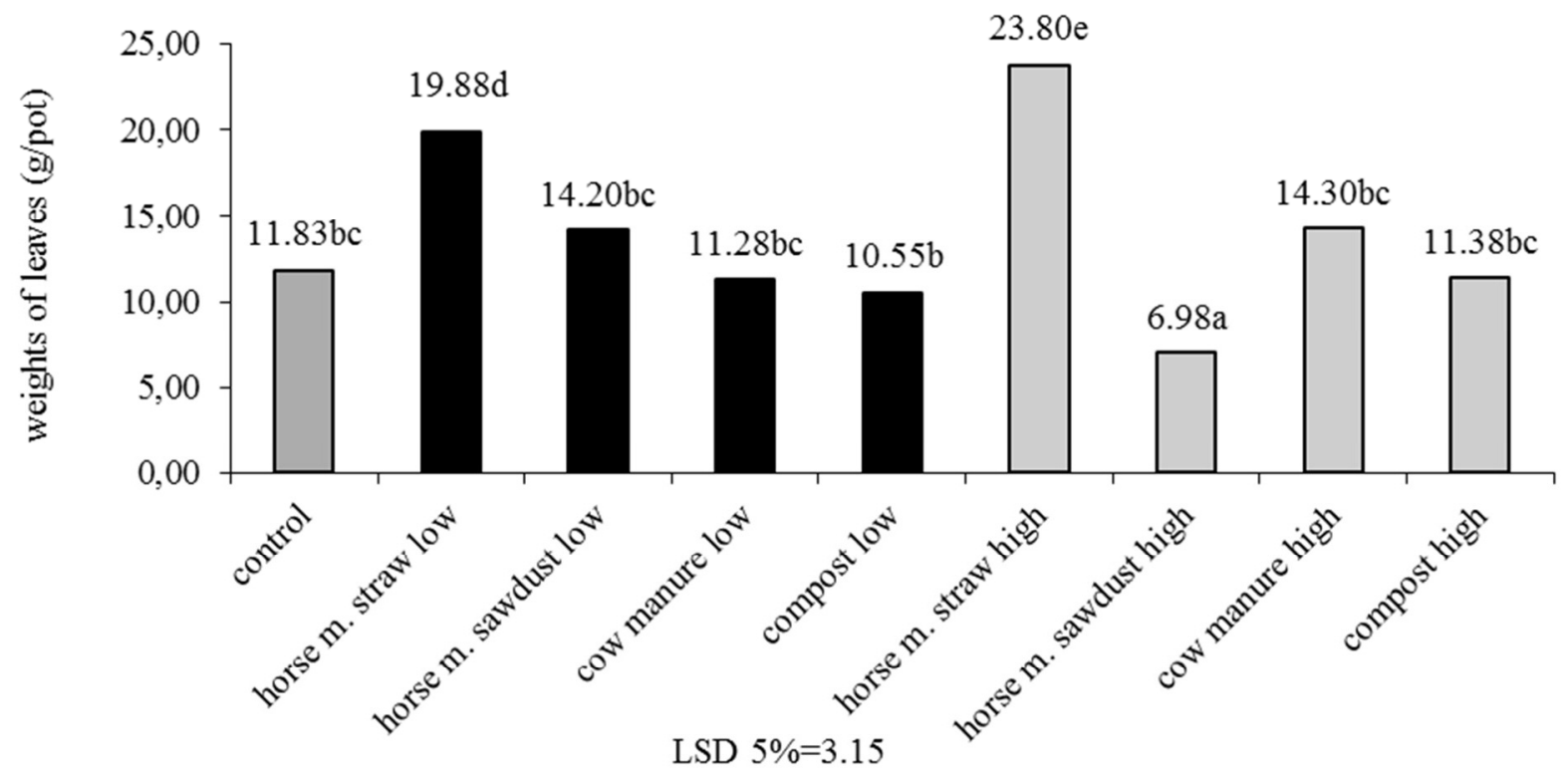

Note: means followed by the same letter are not significantly different (Tukey's studentized range test, $\mathrm{p}<0.05$ ).

Figure 2: Means of weights of roots of spinach

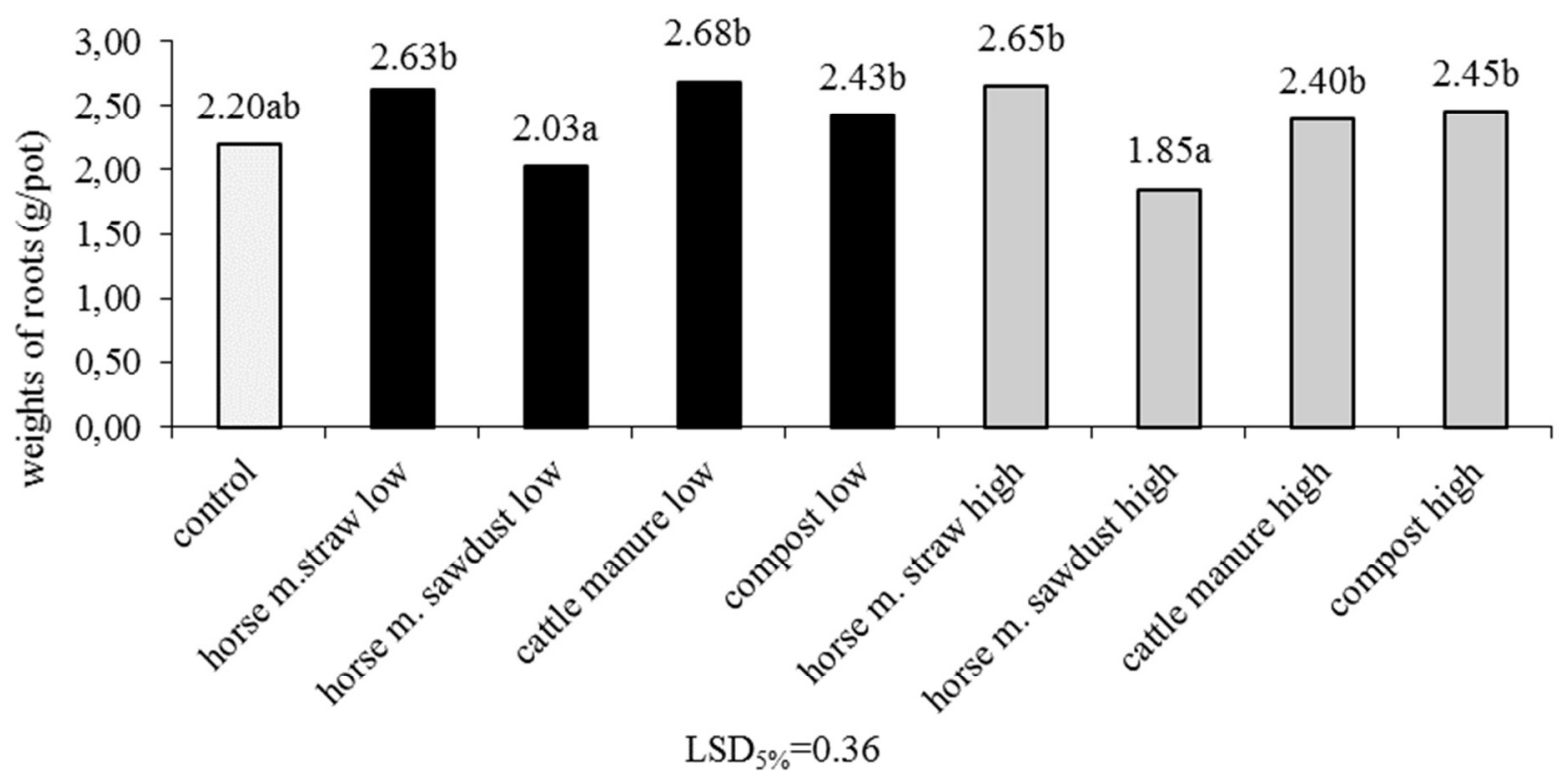

Note: means followed by the same letter are not significantly different (Tukey's studentized range test, $\mathrm{p}<0.05$ ). 
Figure 3: Means of weights of total biomass of spinach

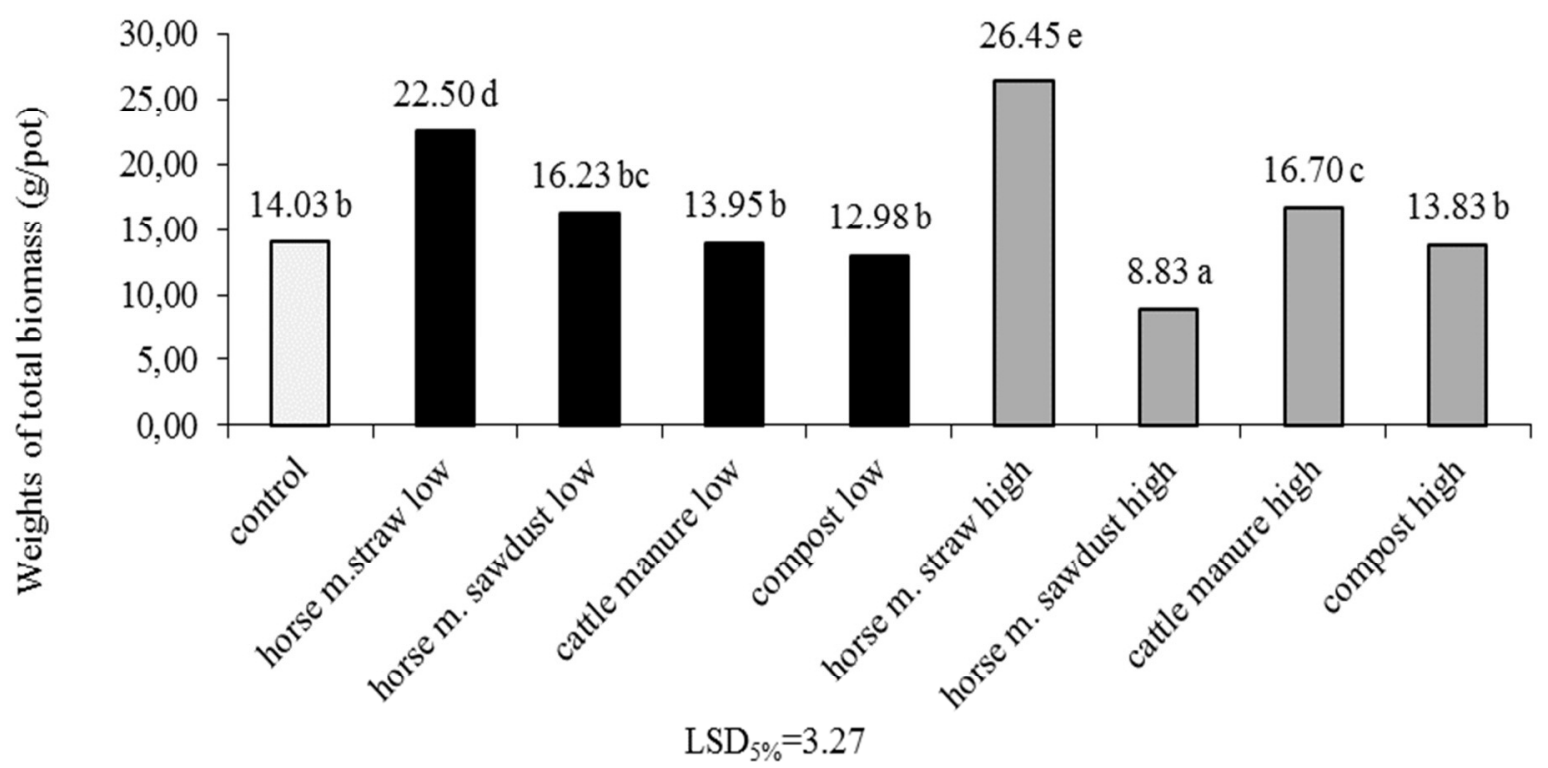

Note: means followed by the same letter are not significantly different (Tukey's studentized range test, $\mathrm{p}<0.05$ ).

The weights of leaves due to different treatments varied strongly from $6.98 \mathrm{~g} \mathrm{pot}^{-1}$ to $23.8 \mathrm{~g} \mathrm{pot}^{-1}$. The addition of horse manure bedded with straw caused the highest increment in weights of leaves of spinach. Even small dose $\left(30 \mathrm{tha}^{-1}\right)$ increased weights (from $11.83 \mathrm{~g}$ pot $^{-1}$ to $\left.19.88 \mathrm{~g} \mathrm{pot}^{-1}\right)$, but the higher dose $\left(60 \mathrm{t} \mathrm{ha}^{-1}\right)$ resulted in further significant increase (to $23.80 \mathrm{~g} \mathrm{pot}^{-1}$ ). The increment of weight of leaves in the treatment of horse manure with straw $\left(30 \mathrm{t} \mathrm{ha}^{-1}\right.$ and $\left.60 \mathrm{t} \mathrm{ha}^{-1}\right)$ were $67.37 \%$ and $101.2 \%$ compared to control, respectively. Although application of smaller dose of horse manure with sawdust $\left(30 \mathrm{t} \mathrm{ha}^{-1}\right)$ did not change the leaves weights, but higher dose $\left(60 \mathrm{t} \mathrm{ha}^{-1}\right)$ caused significant decrease of leaves. This effect might be explained with higher $\mathrm{C} / \mathrm{N}$ ratio and lower nutrient content of horse manure with bedding material of sawdust, which might cause nitrogen immobilisation in soil. Organic materials in one side may improve soil fertility, soil physical characteristics (Hadas et al., 1992), but at the same time if the $\mathrm{C} / \mathrm{N}$ ratio of organic material is high may cause microbial immobilisation and besides may retard plant growth by reducing availability of soil N (Loch and Nosticzius, 1992; Azam, 2002). Many examples have been presented in the literature to demonstrate that plant residues with a high $\mathrm{C} / \mathrm{N}$ ratio retarded plant growth by reducing availability of soil N (Azam et al., 1989; Dilly, 1999). Neither cattle manure nor food waste compost altered the weights of leaves, but it is worth to mention cattle manure with higher dose $\left(60 \mathrm{t} \mathrm{ha}^{-1}\right)$ caused slight increment of leaves.

Horse manure with straw enhanced the growth of roots as well, although the higher dose $\left(60 \mathrm{t} \mathrm{ha}^{-1}\right)$ did not alter the root weights any longer compared to values of lower dose $\left(30 \mathrm{tha}^{-1}\right)$. The other type of horse manure, with bedding material of sawdust did not cause changed root weights either in lower or in higher applied doses. Application of cattle manure significantly increased the root growing and resulted significantly enhanced root weights in these pots. There were no differences between effects of lower $\left(30 \mathrm{tha}^{-1}\right)$ and higher $\left(60 \mathrm{tha}^{-1}\right)$ dose of this organic manure. Food waste compost did not alter the root growing significantly, but it is worth to mention, that in pots with compost the root weights tended to be a little bit higher.

The total dry matter production of spinach varied in high range from $8.83 \mathrm{~g} \mathrm{pot}^{-1}$ to $26.45 \mathrm{~g} \mathrm{pot}^{-1}$. Among treatments the maximum of biomass was achieved with the treatment of horse manure with straw. This type of organic fertilizer caused the greatest favourable changes in the biomass of spinach, the $30 \mathrm{tha}^{-1}$ dose caused $60 \%$ increment, while $60 \mathrm{t} \mathrm{ha}^{-1}$ dose caused $88.52 \%$ increase compared to value of control. The lowest biomass of spinach was obtained with the higher dose of horse manure $\left(60 \mathrm{t} \mathrm{ha}^{-1}\right)$ completed with sawdust. In these pots the weight of total biomass decreased by $37.1 \%$ compared to the value of control. The lower dose of this manure $\left(30 \mathrm{t} \mathrm{ha}^{-1}\right)$ did not alter the biomass significantly. The application of cattle manure with the dose of $30 \mathrm{t} \mathrm{ha}^{-1}$ did not cause marked effect, but the higher amount $\left(60 \mathrm{t} \mathrm{ha}^{-1}\right)$ had a beneficial, significant effect on the biomass.

On the basis of experimental results it can be concluded that the composition of horse manure with straw was the best among applied and examined organic fertilizers. This manure highly increased the growth of leaves, roots and thereby the total biomass of spinach. Conversely, horse manure with sawdust had negative effect on the growth mainly by the effect of higher dose $\left(60 \mathrm{tha}^{-1}\right)$. It draws attention to the limits of applicability of this type of manure. We have found a positive, yield increasing effect of cattle manure. In this experiment the application of food waste compost did not alter the growth of spinach.

\section{Results of $0.01 \mathrm{M} \mathrm{CaCl}_{2}$ soluble nitrogen forms and phosphate in soil}

Concentrations of $0.01 \mathrm{M} \mathrm{CaCl}_{2}$ soluble $\mathrm{NO}_{3}{ }^{-} \mathrm{N}$, $\mathrm{NH}_{4}{ }^{+}-\mathrm{N}$, soluble total $\mathrm{N}$ and $\mathrm{PO}_{4}{ }^{3-}-\mathrm{P}$ of sandy soil are presented in Table 4. 
Means of $\mathrm{NO}_{3}{ }^{-}-\mathrm{N}, \mathrm{NH}_{4}{ }^{+}-\mathrm{N}$, total soluble $\mathrm{N}, \mathrm{PO}_{4}{ }^{3-}-\mathrm{P}\left(\mathrm{mg} \mathrm{kg}^{-1}\right)$ measured in $0.01 \mathrm{M} \mathrm{CaCl}_{2}$ soil extract

\begin{tabular}{|c|c|c|c|c|}
\hline Treatments & $\begin{array}{c}\mathrm{NO}_{3}^{-}-\mathrm{N} \\
\left(\mathrm{mg} \mathrm{kg}^{-1}\right)\end{array}$ & $\begin{array}{l}\mathrm{NH}_{4}{ }^{+}-\mathrm{N} \\
\left(\mathrm{mg} \mathrm{kg}^{-1}\right)\end{array}$ & $\begin{array}{c}\text { total } \mathrm{N} \\
\left(\mathrm{mg} \mathrm{kg}^{-1}\right)\end{array}$ & $\begin{array}{c}\mathrm{PO}_{4}{ }^{3-}-\mathrm{P} \\
\left(\mathrm{mg} \mathrm{kg}^{-1}\right)\end{array}$ \\
\hline 1. unfertilized control & $16.43 \mathrm{a}$ & $7.89 \mathrm{a}$ & $23.8 \mathrm{a}$ & $3.52 \mathrm{a}$ \\
\hline 2. horse manure with straw $\left(30 \mathrm{t} \mathrm{ha}^{-1}\right)$ & $25.39 \mathrm{~b}$ & $7.84 \mathrm{a}$ & $45.6 \mathrm{~b}$ & $4.05 \mathrm{ab}$ \\
\hline 3. horse manure with sawdust $\left(30 \mathrm{t} \mathrm{ha}^{-1}\right)$ & $17.75 \mathrm{a}$ & $6.57 \mathrm{a}$ & $26.1 \mathrm{a}$ & $5.18 \mathrm{c}$ \\
\hline 4. cattle manure $\left(30 \mathrm{t} \mathrm{ha}^{-1}\right)$ & $36.89 \mathrm{c}$ & $11.29 \mathrm{c}$ & $43.1 \mathrm{~b}$ & $4.38 \mathrm{~b}$ \\
\hline 5. food waste compost $\left(30 \mathrm{t} \mathrm{ha}^{-1}\right)$ & $14.98 \mathrm{a}$ & $11.25 \mathrm{c}$ & $29.4 \mathrm{a}$ & $3.99 \mathrm{ab}$ \\
\hline 6. horse manure with straw $\left(60 \mathrm{t} \mathrm{ha}^{-1}\right)$ & $32.43 \mathrm{bc}$ & $8.17 \mathrm{a}$ & $45.5 \mathrm{~b}$ & $4.04 \mathrm{ab}$ \\
\hline 7. horse manure with sawdust $\left(60 \mathrm{tha}^{-1}\right)$ & $14.25 \mathrm{a}$ & $7.44 \mathrm{a}$ & $34.1 \mathrm{a}$ & $4.98 \mathrm{c}$ \\
\hline 8. cattle manure $\left(60 \mathrm{t} \mathrm{ha}^{-1}\right)$ & $45.26 \mathrm{~cd}$ & $9.04 \mathrm{ab}$ & $56.4 \mathrm{~b}$ & $3.83 \mathrm{ab}$ \\
\hline 9. food waste compost $\left(60 \mathrm{t} \mathrm{ha}^{-1}\right)$ & $22.52 \mathrm{ab}$ & $9.70 \mathrm{~b}$ & $37.2 \mathrm{ab}$ & $4.22 \mathrm{~b}$ \\
\hline
\end{tabular}

Note: means followed by the same letter are not significantly different (Tukey's studentized range test, $\mathrm{p}<0.05$ ).

By the end of the experiment the amount of the $0.01 \mathrm{M} \mathrm{CaCl}_{2}$ soluble $\mathrm{NO}_{3}-\mathrm{N}$ in soil varied in wide range from $14.25 \mathrm{mg} \mathrm{kg}^{-1}$ to $45.26 \mathrm{mg} \mathrm{kg}^{-1}$. It was measured significantly higher $\mathrm{NO}_{3}-\mathrm{N}$ in pots with treatment of horse manure with straw and cattle manure either in lower or in higher doses. As it was expected, the $\mathrm{NO}_{3}-\mathrm{N}$ in pots with lower manure dose was lower, than that of higher manure dose. In lower dose of food waste compost treatment the quantity of $\mathrm{NO}_{3}-\mathrm{N}$ did not differ from values of control, but higher dose $\left(60 \mathrm{tha}^{-1}\right)$ caused a little bit enhanced value. The highest $\mathrm{NO}_{3}-\mathrm{N}$ concentration was measured in pots with cattle manure treatment, which proved high nitrogen supply ability of this organic fertilizer. While among applied organic fertilizers horse manure with straw had the largest nitrogen content, nonetheless the measurable soil nitrate level by the effect of this manure was not the biggest one. This might be caused that in these pots higher plant biomass was produced and therefore higher amount of nitrate was taken up by plants.

The results demonstrate that in this experiment the $0.01 \mathrm{M} \mathrm{CaCl}_{2}$ extractable $\mathrm{NO}_{3}-\mathrm{N}$ was a larger pool for plant nutrition in sandy soil than that of $\mathrm{NH}_{4}-\mathrm{N}$. The amounts of $0.01 \mathrm{M} \mathrm{CaCl}_{2}$ extractable $\mathrm{NH}_{4}-\mathrm{N}$ were lower in all pots compared with nitrate values. The highest $\mathrm{NH}_{4}-\mathrm{N}$ was found in treatment with cattle manure and food waste compost in application of lower dose. In case of horse manure treatment it was not measured notable different $\mathrm{NH}_{4}{ }^{+}-\mathrm{N}$ values compared to control.

Results of statistical analysis indicated significant differences between values of $0.01 \mathrm{M} \mathrm{CaCl}_{2}$ soluble total- $\mathrm{N}$ in case of some treatments compared to control. Application of lower dose of horse manure with sawdust and compost did not change the quantity of $\mathrm{CaCl}_{2}$-total $\mathrm{N}$, but other organic fertilizers caused significantly higher soluble $\mathrm{N}$ values. The higher dose of fertilizers, except for horse manure with straw, further increased the $0.01 \mathrm{M} \mathrm{CaCl}_{2}$ soluble total $\mathrm{N}$ of soil, compared to value of lower dose.

All of applied organic fertilizers with different origin altered the $0.01 \mathrm{M} \mathrm{CaCl}_{2} \mathrm{PO}_{4}^{3-}-\mathrm{P}$ content of soil. The horse manure with sawdust and the lower rate of cattle manure caused the highest $0.01 \mathrm{M} \mathrm{CaCl}_{2} \mathrm{PO}_{4}^{3-}-\mathrm{P}$ value. Application of horse manure with straw and lower rate of food waste compost did not change these values. The highest dose of organic fertilizer did not cause increased $0.01 \mathrm{M} \mathrm{CaCl}_{2} \mathrm{PO}_{4}{ }^{3-}-\mathrm{P}$ values compared to values of lower doses.

\section{CONCLUSIONS}

On the bases of results it can be concluded that comparing the effects of $30 \mathrm{tha}^{-1}$ dose of fertilizers, the horse manure with straw caused the highest increment in weights of leaves, roots and total biomass of spinach compared to other treatments and control. The higher dose $\left(60 \mathrm{t} \mathrm{ha}^{-1}\right)$ further increased these parameters. Horse manure with straw greatly increased the amount of $0.01 \mathrm{M} \mathrm{CaCl}_{2}$ soluble $\mathrm{NO}_{3}-\mathrm{N}$, total $\mathrm{N}$ and $\mathrm{PO}_{3}{ }^{4-}-\mathrm{P}$ in soil.

Application of $30 \mathrm{t} \mathrm{ha}^{-1}$ horse manure with sawdust did not change the leave weights but higher dose $\left(60 \mathrm{t} \mathrm{ha}^{-1}\right)$ caused significant decrease of these values. The different bedding material changed the composition and the effects of horse manure. The yield depressive effect of higher dose might be explained by its unfavourable composition, by higher $\mathrm{C} / \mathrm{N}$ ratio and lower nutrient content that might cause nitrogen immobilisation in soil. Horse manure with sawdust did not alter the soluble nitrogen forms of soil by the end of the experiment, but caused increased $0.01 \mathrm{M} \mathrm{CaCl}_{2}$ soluble $\mathrm{PO}_{3}{ }^{4-}-\mathrm{P}$ values.

Lower dose of cattle manure did not cause significant change in the dry matter accumulation of spinach, but higher amount $\left(60 \mathrm{t} \mathrm{ha}^{-1}\right)$ enhanced leaves weights and total biomass weights as well. This type of manure significantly influenced the available nutrients of soil, caused increased $0.01 \mathrm{M} \mathrm{CaCl}-\mathrm{NO}_{3}-\mathrm{N}$, total- $\mathrm{N}$ and $\mathrm{PO}_{3}{ }^{4-}-\mathrm{P}$ values by the end of the experiment. There were no excessive differences between effects of lower $\left(30 \mathrm{tha}^{-1}\right)$ and higher $\left(60 \mathrm{tha}^{-1}\right)$ dose of this organic manure.

Food waste compost did not alter either the leaves or the root growing significantly, but it is worth to mention, that in pots with compost the root weights tended to be a little bit higher. Higher doses of organic fertilizers caused increased soluble $\mathrm{N}$ of soil in some of discussed cases but the differences between values of lower and higher doses was not significant. The application of food waste compost in lower dose did not alter the $0.01 \mathrm{M} \mathrm{CaCl}_{2}$ soluble $\mathrm{PO}_{3}{ }^{4-}-\mathrm{P}$, the higher amount $\left(60 \mathrm{tha}^{-1}\right)$ caused an increased value.

Finally, it can be concluded, that in this experiment the plant nutrition effect of horse manure with straw 
was the best among applied and examined organic fertilizers on humic sandy soil. The horse manure with straw enhanced spinach growth most significantly, compared to other treatments and the non-treated control, resulting the highest weights of leaves and roots of spinach.

At the same time, even small dose $\left(30 \mathrm{t} \mathrm{ha}^{-1}\right)$ of this fertilizer caused increased plant available nitrogen and phosphorus of soil. The higher rate of it further increased the extractable nitrate content. The horse manure with sawdust applied in lower dose did not alter the leaves and roots weights, but higher portion $\left(60 \mathrm{t} \mathrm{ha}^{-1}\right)$ caused significantly decreased plant biomass. The results proved that the bedding material may significantly alter the composition of manure and change the plant nutrition effect of organic fertilizer. Cattle manure and food waste compost in both applied doses enhanced plant growth but a much smaller extent. Both fertilizers increased the plant available nitrogen forms and phosphorus content of soil, but cattle manure caused higher increase.

\section{ACKNOWLEDGEMENTS}

This study was supported by Hungarian-Ukrainian Intergovernmental S\&T Cooperation Programme for 2009-2010" R\&D bilateral project "Change of soils ecological characteristics of Ukraine and Hungary in the conditions of anthropogenic transformed ecosystems and optimization of biological processes of plants primary feed elements mobilization."

\section{REFERENCES}

Azam, F. (2002): Added nitrogen interaction in the soil-plant system - a review. Pakistan J. Agron. 1: 54-59.

Azam, F.-Stevenson, F. J.-Mulvaney, R. L. (1989): Chemical extraction of newly immobilised $15 \mathrm{~N}$ and native soil $\mathrm{N}$ as influenced by substrate addition rate and soil treatment. Soil Biol. Biochem. 21: 715-722.

Buzás I. (1993): Talaj- és agrokémiai vizsgálati módszerkönyv 1. INDA 4231 Kiadó. Budapest.

Cayuela, M. L.-Sinicco, T.-Mondini, C. (2008): Mineralization dynamics and biochemical properties during initial decomposition of plant and animal residues in soil. Appl. Soil Ecol. 41: 118-127.

Cegarra, J.-Alburquerque, A.-Gonzálvez, J.-Tortosa, G. D.-Chaw, D. (2006): Effects of the forced ventilation on composting of a solid olive-mill by-product ("alperujo") managed by mechanical turning. Waste Manage. 26: 1377-1383.

Chang, J. I.-Tin-En, Hsu (2008): Effects of compositions on food waste composting. Bioresource Technology. 99. 17: 256-278.

Clark, M. S.-Horwath, W. R.-Shennan, C.-Scattle, K. M. (1998): Changes in soil chemical properties resulting from organic and low-input farming practices. Agron. J. 90: 662-671.

Council of the European Union (1999): Directive 1999/31/EC, of 26 April 1999 on the landfill of waste.

Dilly, O. (1999): Nitrogen and phosphorus requirement of the microbiota in soils of the Bornho"ved Lake district. Plant Soil. 212: $175-183$

Elherradi, E.-Soudi, B.-Chiang, C.-Elkcemi, K. (2005): Evaluation of nitrogen fertilizing value of composted household solid waste under greenhouse conditions. Agronomy for sustainable development. 25. 2: 169-175.

Fleming, K.-Hessel, E. F.-van de Weghe, H. F. A.--Orof, Dr. Ir. (2008): Evaluation of Factors Influencing the Generation of Ammonia in Different Bedding Materials Used for Horse Keeping. Journal of Equine Veterinary Science. 28. 4: 223-231.

Hadas, A.-Molina, J. A. E.-Feigenbaum, S.-Clapp, C. E. (1992) Factors affecting nitrogen immobilization in soil as estimated by simulation models. Soil Sci. Soc. Am. J. 56: 1481-1486.

Hati, K. M.-Mandal, K. G.-Misra, A. K.-Ghosh, P. K.-Bandyopadhyay, K. K. (2008): Effects of inorganic fertilizer and farmyard manure on soil physical properties, root distribution, and water-use efficiency of soybean in Vertisols of central India. Bioresource Technology. 97. 16: 2182-2188.
Houba, V. J. G.-Jászberényi, I.-Loch, J. (1991): Application of 0.01 $\mathrm{M} \mathrm{CaCl}_{2}$ as a single extraction solution for evaluation of the nutritional status of Hungarian soils. Debreceni Agrártudományi Egyetem Tudományos Közleményei. 30: 85-89.

Irshad, M.-Yamamoto, S.-Eneji, A. E.-Endo, T.-Honna, T. (2002): Urea and manure effect on growth and mineral contents of maize under saline conditions. Journal of Plant Nutrition. 25. 1: 189-200.

Jászberényi, I.-Loch, J.-Sarkadi, J. (1994): Experiences with $0.01 \mathrm{M}$ $\mathrm{CaCl}_{2}$ as an extraction reagent for use as a soil testing procedure in Hungary. Commun. Soil Sci. Plant Anal. 25: 1771-1777.

Jongtae, L. (2010): Effect of application methods of organic fertilizer on growth, soil chemical properties and microbial densities in organic bulb onion production. Scientia Horticulturae. 124. 3: 299-305.

Levis, J. W.-Barlaz, M. A.-Themelis, N. J.-Ulloa, P. (2010): Assessment of the state of food waste treatment in the United States and Canada. Waste Management. 30. 8-9: 1486-1494.

Liebig, M. A.-Doran, J. W. (1999): Impact of organic production practices on soil quality indicators. J. Environ. Qual. 28. 1601-1609.

Loch J.-Nosticzius Á. (1992): Agrokémia és növényvédelmi kémia Mezőgazda Könyvkiadó. Budapest.

Pathak, D. V.-Khurana, A. L.-Singh, S. (1997): Biofertilizers for enhancement of crop productivity - a review. Agric. Rev. 18: 155-166.

Roberts, P.-Edwards-Jones, G.-Jones, D. L. (2007): In-vessel cocomposting of green waste with biosolids and paper waste. Compost Science and Utilization. 15: 272-282.

Saxena, A. K.-Tilak, K. V. B. R. (1994): Interaction among beneficial soil microorganisms. Indian J. Microbiol. 34: 91-106.

Sharpley, A.-Moyer, B. (2000): Phosphorus forms in manure and compost and their release during simulated rainfall. Journal of environmental quality. 29. 5: 1462-1469.

Vágó, I.-Sipos, M.-Tolner, L.-Czinkota, I.-Szilágyi, G.-Issa, I.Kátai, J. (2015): Plant growth and potassium supply dynamics on a chernozem soil of a long-term fertilization and irrigation experiment with maize monoculture in Hungary. Soil-Water Journal. Special Issue. 6-12. 